\title{
Emendation of the genus Flammeovirga and Flammeovirga aprica with the proposal of Flammeovirga arenaria nom. rev., comb. nov. and Flammeovirga yaeyamensis sp. nov.
}

\author{
Mai Takahashi, Ken-ichiro Suzuki and Yasuyoshi Nakagawa \\ Biological Resource Center (NBRC), Department of Biotechnology, National Institute of \\ Technology and Evaluation, 2-5-8 Kazusakamatari, Kisarazu, Chiba 292-0818, Japan
}

Correspondence

Yasuyoshi Nakagawa

nakagawa@nbrc.nite.go.jp
The genus Flammeovirga, a member of the phylum Bacteroidetes, was created to accommodate the misclassified species [Cytophaga] aprica (Nakagawa et al., 1997). It currently consists of a single species, Flammeovirga aprica, a Gram-negative, aerobic, heterotrophic, gliding, orangepigmented marine bacterium possessing menaquinone-7 (MK-7). It has been reported that the genus Microscilla is very heterogeneous and that 'Microscilla arenaria' Lewin 1969 is also related to the genus Flammeovirga (Nakagawa et al., 2002), however, to date, this species name has not been validly published.

During a survey of microbial communities within subtropical zones of Japan (Nakagawa, 2004), five strains, IR25$3^{\mathrm{T}}$, IR27-3, IR28-1, IS22-1 and IS26-1, were isolated from seaweeds, coastal sands and dead leaves. These samples were collected along the seashores of Iriomote and Ishigaki Islands in October 2001 (see Supplementary Table S1 in IJSEM Online). These islands are located at $24^{\circ} 20^{\prime} \mathrm{N} 123^{\circ}$ $45^{\prime} \mathrm{E}$ and $24^{\circ} 20^{\prime} \mathrm{N} 124^{\circ} 9^{\prime} \mathrm{E}$, respectively and belong to the Yaeyama Island group. In this paper, we describe taxonomic

The GenBank/EMBL/DDBJ accession numbers for the $16 \mathrm{~S}$ rRNA gene sequences of strains NBRC $15941^{\top}$, IR25-3 ${ }^{\top}$, IR27-3, IR28-1, IS22-1 and IS26-1 are AB247553-AB247558, respectively.

Tables detailing the sources of the isolates, their cellular fatty acid contents and variable phenotypic characteristics between isolates are available as supplementary material in IJSEM Online. studies on the five novel strains and ' $M$. arenaria' NBRC 15982.

Genomic DNA extraction and 16S rRNA gene sequencing were conducted according to previously published procedures (Nakagawa et al., 2002). Sequence data obtained were aligned with those of representative members of the phylum Bacteroidetes by using CLUSTAL_X (Thompson et al., 1997) and then manually aligned following the 16S rRNA secondary structure of Escherichia coli (Gutell et al., 1994) by using the Se-Al v2.0 alignment editor (available at http:// evolve.zoo.ox.ac.uk/). A phylogenetic tree was constructed on the basis of the neighbour-joining method (Saitou \& Nei, 1987 ) and $K_{\text {nuc }}$ values (Kimura, 1980) (Fig. 1). The topology of the tree was evaluated by bootstrap analysis (Felsenstein, 1985) using 1000 replicates. The almost-complete $16 S$ rRNA gene sequences, ranging from $E$. coli equivalent positions (Brosius et al., 1978) 28 to 1494, were determined for the five novel isolates and for F. aprica NBRC $15941^{\mathrm{T}}$. All of the novel isolates showed identical 16S rRNA gene sequences. Phylogenetic analysis of strain IR25- $3^{\mathrm{T}}$ and ' $M$. arenaria' NBRC 15982 revealed that they were closely related to the genus Flammeovirga. 16S rRNA gene sequence similarities between F. aprica NBRC $15941^{\mathrm{T}}$ and strain IR25-3 ${ }^{\mathrm{T}}$ and ' $M$. arenaria' NBRC 15982 were $95 \cdot 2$ and $98 \cdot 1 \%$, respectively. Gene sequence similarity between strain IR25-3 ${ }^{\mathrm{T}}$ and ' $M$. arenaria' NBRC 15982 was $95 \cdot 9 \%$.

DNA-DNA hybridizations were performed with photobiotin-labelled probes in microplate wells as described by 


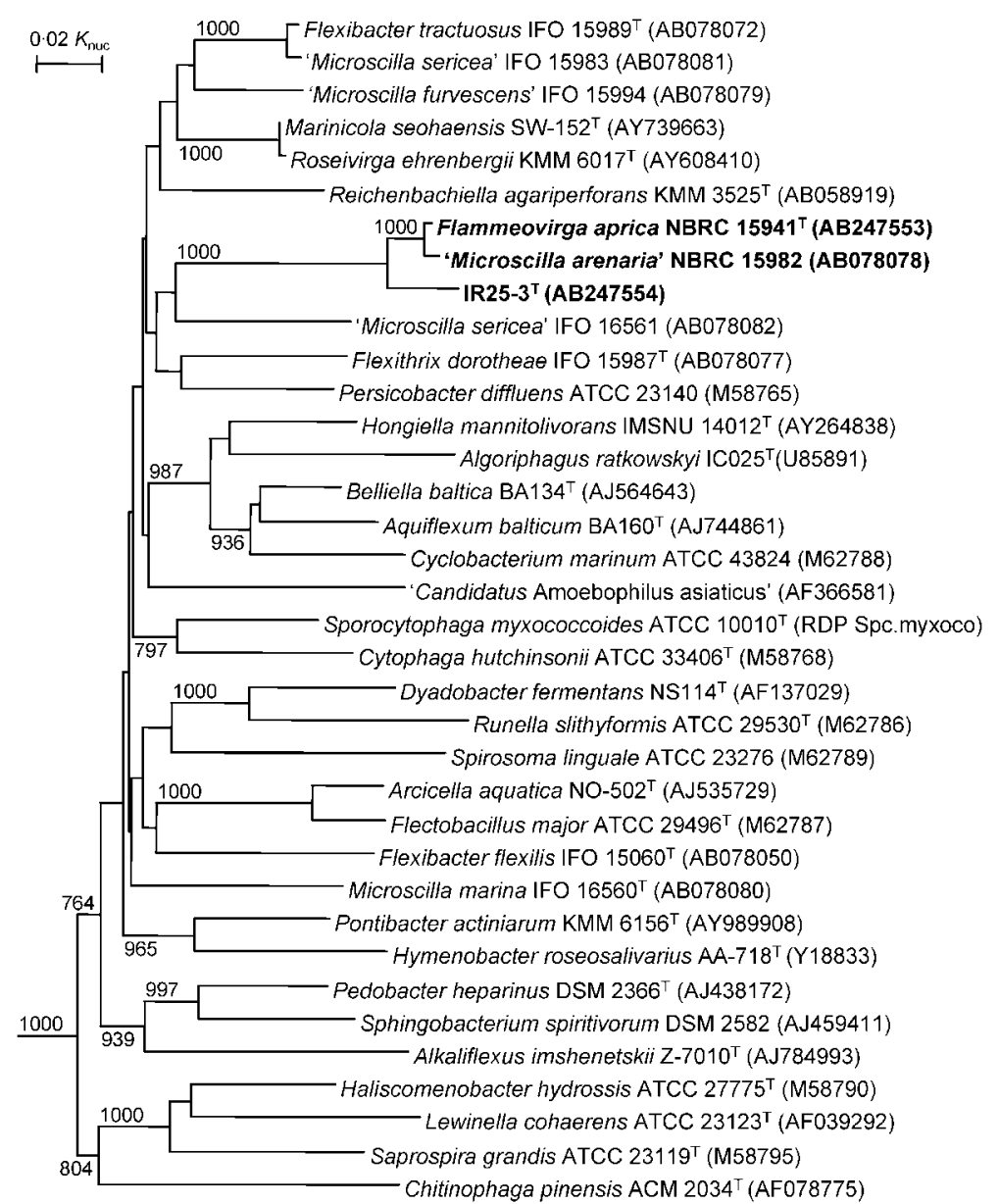

Fig. 1. Neighbour-joining tree showing the phylogenetic positions of ' $M$. arenaria' NBRC 15982 and strain IR25-3' ${ }^{\top}$ based on 16S rRNA gene sequences. Bootstrap values greater than 700 in 1000 replicates are shown. Bar, $0.02 K_{\text {nuc }}$.
Ezaki et al. (1989). The hybridization temperature was $48.7^{\circ} \mathrm{C}$ in $2 \times$ SSC buffer containing $25 \%$ formamide. The five novel isolates constituted a single species as their DNADNA relatedness values ranged from 73 to $110 \%$ when IR $25-3^{\mathrm{T}}$ was used as the probe. Strain IR25- $3^{\mathrm{T}}$ exhibited 12-16\% DNA-DNA relatedness with $F$. aprica NBRC $15941^{\mathrm{T}}$ and $18-27 \%$ relatedness with ' $M$. arenaria' NBRC 15982. The DNA-DNA binding value between $F$. aprica NBRC $15941^{\mathrm{T}}$ and ' $M$. arenaria' NBRC 15982 was $11-21 \%$. These results indicate that $F$. aprica NBRC $15941^{\mathrm{T}}$, ' $M$. arenaria' NBRC 15982 and the five novel isolates constitute three separate species.

The $\mathrm{G}+\mathrm{C}$ content of DNA was determined according to Mesbah et al. (1989). The DNA G + C contents of the novel isolates were $33 \cdot 4-35 \cdot 7 \mathrm{~mol} \%$. The value for ' $M$. arenaria' NBRC 15982 was $31 \cdot 8 \mathrm{~mol} \%$. These values were similar to the value of $34 \cdot 2 \mathrm{~mol} \%$ obtained in this study for F. aprica NBRC $15941^{\mathrm{T}}$. To determine whole-cell fatty acid content, all strains were grown on Bacto marine agar 2216 (Difco) at $25{ }^{\circ} \mathrm{C}$ for $24 \mathrm{~h}$. Fatty acid methyl esters were prepared and analysed according to the standard protocol of the Microbial Identification System (Microbial ID). F. aprica NBRC $15941^{\mathrm{T}}$, 'M. arenaria' NBRC 15982 and the novel isolates had similar fatty acid contents in which the dominant fatty

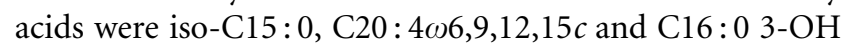

(see Supplementary Table S2 in IJSEM Online). The presence

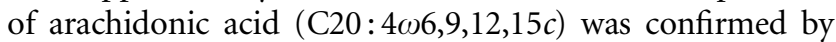
using a GC-MS (5973 Network MSD; Agilent) with commercially available standards. Respiratory quinones were extracted according to Nakagawa \& Yamasato (1993) and determined by using a LC-MS ( $8000 \alpha$; Shimadzu). MK7 was found to be the major respiratory quinone in all strains. Using the bathochromic shift test with $20 \%(\mathrm{w} / \mathrm{v})$ KOH (Fautz \& Reichenbach, 1980), no flexirubin-type pigments were detected in any of the strains. Carotenoids were extracted as described by Schmidt et al. (1994) and their light absorption spectra were investigated by using a UV-visible spectrophotometer (UV-1650PC; Shimadzu). It has been previously reported that F. aprica NBRC $15941^{\mathrm{T}}$ and ' $M$. arenaria' NBRC 15982 contained saproxanthin (Reichenbach, 1989a, b). In this study, the carotenoids of the novel isolates were identified as saproxanthin as they showed identical spectra to those of F. aprica NBRC $15941^{\mathrm{T}}$ and ' $M$. arenaria' NBRC 15982. Cellular polyamines were prepared and analysed according to Hamana et al. (1995). In addition to cadaverine, spermidine and agmatine were detected for the novel isolates when they were cultivated on Bacto marine agar. It has been previously reported that putrescine, cadaverine, spermidine and agmatine are present in ' $M$. arenaria' NBRC 15982 (Hosoya \& Hamana, 2003). 
Gliding motility was determined as described by Perry (1973). Anaerobic growth was examined by using the Anaeropack system (Mitsubishi Gas Chemical). The ability of strains to degrade agar, alginic acid, casein, cellulose, carboxymethylcellulose, chitin, DNA, inulin, aesculin, gelatin, starch, Tween 80 , tyrosine and urea was investigated according to the methods of Lewin \& Lounsbery (1969), Smibert \& Krieg (1981) and Barrow \& Feltham (1993) with media prepared with Daigo's artificial seawater SP (Wako Pure Chemicals). Production of indole, $\mathrm{H}_{2} \mathrm{~S}$ and the activities of oxidase, urease and nitrate reductase were also examined as described by Smibert \& Krieg (1981). Oxidation or fermentation of glucose (O-F test; Hugh \& Leifson, 1953) was investigated by using OF basal media (Eiken Kizai) prepared with artificial seawater. For growth responses at different temperatures $\left(5-45^{\circ} \mathrm{C}\right)$ and $\mathrm{pH}$ (3-11), one-fifth strength LBM medium was used (Suzuki et al., 2001) for cultivation. The potential of the strains to metabolize 95 different carbon sources was examined by using GN2 Microplates (Biolog) with the method modified for marine bacteria as described by Rüger \& Krambeck (1994). Acid production from various carbon sources was determined by using the API $50 \mathrm{CH}$ test (bioMérieux) with cells grown on a medium composed of $50 \% \mathrm{CHB} / \mathrm{E}$ medium with artificial seawater (Lau et al., 2005). The phenotypic characteristics of $F$. aprica NBRC $15941^{\mathrm{T}}$, ' $M$. arenaria' NBRC 15982 and the novel isolates are given in the genus and species descriptions and in Table 1 (see also Supplementary Table S3 in IJSEM Online).

According to a phylogenetic analysis of 16S rRNA gene sequences, we have concluded that ' $M$. arenaria' NBRC 15982 and the novel isolates should be classified in the genus Flammeovirga. In the original description of the genus Flammeovirga, it was stated that oxidase activity and degradation of gelatin were positive and that catalase activity was negative. However, we found that ' $M$. arenaria' NBRC 15982 did not produce oxidase and F. aprica NBRC $15941^{\mathrm{T}}$ and the novel isolates showed catalase activity. In addition, degradation of gelatin was not detected in F. aprica NBRC $15941^{\mathrm{T}}$ or ' $M$. arenaria' NBRC 15982 . Thus, we propose the emendation of the genus Flammeovirga to include 'Microscilla arenaria' NBRC 15982 and our novel isolates. F. aprica NBRC $15941^{\mathrm{T}}$, 'Microscilla arenaria' NBRC 15982 and the five novel isolates can be distinguished from each other by the phenotypic characteristics summarized in Table 1. These results suggest that 'Microscilla arenaria' NBRC $15982^{\mathrm{T}}$ and the novel isolates represent two separate species of the genus Flammeovirga. We propose to transfer 'Microscilla arenaria' to the genus Flammeovirga as Flammeovirga arenaria nom. rev., comb. nov. Strains IR25-3 ${ }^{\mathrm{T}}$, IR27-3, IR28-1, IS22-1 and IS26-1 are proposed as members of a novel species, Flammeovirga yaeyamensis sp. nov. According to the rules of Latin and latinization, the original spelling of Flammeovirga should be corrected to Flammeivirga, however, the original version of the name, Flammeovirga, has been retained according to the new Rule 61 of the Bacteriological Code (Euzéby, personal communication).

\section{Emended description of the genus Flammeovirga}

Flammeovirga (Flam.me.o.vir'ga. L. adj. flammeus firecoloured; L. fem. n. virga rod; L. fem. n. Flammeovirga firecoloured rod).

Cells are Gram-negative, aerobic, chemo-organotrophic, asporogenic, long rods that are $0 \cdot 4-0 \cdot 9 \mu \mathrm{m}$ wide and $1.7-96 \mu \mathrm{m}$ long or longer. Motile by gliding. Cell mass is orange to reddish orange. Oxidase and catalase activities are variable. Major respiratory quinone is MK-7. Saproxanthin is present as the major carotenoid pigment. Flexirubin-type pigments are absent. Predominant cellular fatty acids are iso-C15:0, $\mathrm{C} 20: 4 \omega 6,9,12,15 c$ and $\mathrm{C} 16: 03-\mathrm{OH}$. Members of the genus are marine organisms that require $\mathrm{NaCl}$ or seawater for growth. Growth is supported by $\mathrm{NaCl}$ alone. Nitrate is reduced. Agar, alginic acid, aesculin and starch are degraded. The $\mathrm{G}+\mathrm{C}$ content of DNA is $31-36 \mathrm{~mol} \%$. The type species of the genus is Flammeovirga aprica.

\section{Emended description of Flammeovirga aprica}

Flammeovirga aprica (a' pri.ca. L. fem. adj. aprica sunlit, sunloving).

Displays the following properties in addition to those given in the genus description. Cells are long rods, $0.5-0.9 \mu \mathrm{m}$ wide and 1.7-96 $\mu \mathrm{m}$ long or longer. Colonies spread and produce large gelase fields and deep craters in agar plates. Growth is detected at $15-30^{\circ} \mathrm{C}$, with the optimum growth yield at $25^{\circ} \mathrm{C}$. The $\mathrm{pH}$ range for growth is $6-8$ with the optimum growth yield at $\mathrm{pH} 7$. Growth occurs at $1-5 \%$ $\mathrm{NaCl}$ with the optimum growth yield at $3 \%$. Oxidase and catalase activities are positive. Urease activity is negative. Agar, alginic acid, carboxymethylcellulose, DNA, aesculin and starch are degraded, but cellulose, chitin, inulin, gelatin, Tween 80 and tyrosine are not degraded. Casein is weakly degraded. $\mathrm{H}_{2} \mathrm{~S}$ is produced, but indole is not. O-F test of glucose is fermentative. Utilization (Biolog GN2 microplate data) is observed for $\alpha$-cyclodextrin, dextrin, L-fucose, glycogen, D-galactose, gentiobiose, $\alpha$-D-glucose, DL-lactic acid, $\alpha$-D-lactose, D-trehalose, lactulose, maltose, glucose 1phosphate, cellobiose, D-mannose, monomethyl succinate, glycyl L-glutamic acid and glucose 6-phosphate, but not for D-melibiose, urocanic acid, L-ornithine, L-rhamnose, Lalanyl glycine, $N$-acetyl-D-glucosamine or L-threonine. Acid production (API $50 \mathrm{CH}$ data) is positive for D-xylose, galactose, $\mathrm{N}$-acetylglucosamine, amygdalin, aesculin, salicin, cellobiose, maltose, lactose, starch, glycogen and gentiobiose and weakly positive for ribose, glucose, mannose and L-fucose. Acid is not produced from rhamnose, mannitol, sorbitol, methyl $\alpha$-D-glucoside, arbutin, melibiose, melezitose, raffinose or xylitol. The major cellular

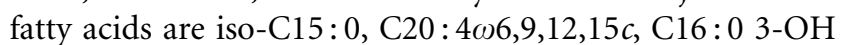
and $\mathrm{C} 14: 0$. The DNA G $+\mathrm{C}$ content of the type strain is $34 \cdot 2 \mathrm{~mol} \%$.

The type strain is NBRC $15941^{\mathrm{T}}\left(=\right.$ ATCC $23126^{\mathrm{T}}=\mathrm{CIP}$ $104807^{\mathrm{T}}$ ). 
Table 1. Phenotypic differentiation of Flammeovirga species

Taxa: 1, Flammeovirga aprica NBRC $15941^{\mathrm{T}}$; 2, Flammeovirga ('Microscilla') arenaria NBRC $15982^{\mathrm{T}}$; 3, Flammeovirga yaeyamensis sp. nov. $(\mathrm{n}=5)$. All strains are negative for the utilization of i-erythritol, $p$-hydroxyphenylacetic acid, bromosuccinic acid, D-fructose, methyl $\beta$-D-glucoside, cis-aconitic acid, itaconic acid, succinamic acid, hydroxy L-proline, inosine, D-psicose, citric acid, glucuronamide, L-leucine, D-raffinose, formic acid, $\alpha$-ketoglutaric acid, Tween 40, D-galactonic acid lactone, $\alpha$-ketovaleric acid, D-alanine, L-phenylalanine, phenylethylamine, Tween 80, D-sorbitol, D-galacturonic acid, putrescine, $\mathrm{N}$-acetyl-D-galactosamine, myo-inositol, sucrose, D-gluconic acid, malonic acid, L-pyroglutamic acid, 2-aminoethanol, D-glucosaminic acid, D-serine, 2,3-butanediol, adonitol, turanose, D-glucuronic acid, quinic acid, glycerol, L-arabinose, xylitol, $\alpha$-hydroxybutyric acid, D-saccharic acid, L-glutamic acid, DL- $\alpha$-glycerol phosphate, D-arabitol, D-mannitol, methyl pyruvate, $\beta$-hydroxybutyric acid, sebacic acid, DL-carnitine, $\gamma$-hydroxybutyric acid, succinic acid and $\gamma$-aminobutyric acid with the Biolog GN2 Microplate. All strains are negative for acid production from glycerol, erythritol, D-arabinose, L-arabinose, L-xylose, adonitol, methyl $\beta$-Dxyloside, dulcitol, inositol, inulin, D-turanose, D-lyxose, D-tagatose, D-fucose, D-arabitol, L-arabitol, gluconate and 2-ketogluconate with the API $50 \mathrm{CH}$ test. The optimum $\mathrm{pH}$ for growth was 7 for all species. +, Positive; -, negative; v, variable results among strains; w, weakly positive; +/W, positive or weakly positive.

\begin{tabular}{|c|c|c|c|}
\hline Characteristic & 1 & 2 & 3 \\
\hline \multicolumn{4}{|l|}{ Growth: } \\
\hline Temperature range $\left({ }^{\circ} \mathrm{C}\right)$ & $15-30$ & $10-30$ & $15-35$ \\
\hline Optimum temperature $\left({ }^{\circ} \mathrm{C}\right)$ & 25 & 25 & 30 \\
\hline $\mathrm{pH}$ & $6-8$ & $6-8$ & $6-10$ \\
\hline \multicolumn{4}{|l|}{ Degradation of: } \\
\hline Carboxymethylcellulose & + & - & + \\
\hline Casein & $\mathrm{W}$ & $\mathrm{W}$ & - \\
\hline Gelatin & - & - & + \\
\hline Inulin & - & - & + \\
\hline Tween 80 & - & - & + \\
\hline DNase & + & - & + \\
\hline Oxidase & + & - & $+/ \mathrm{w}$ \\
\hline Catalase & + & - & $\mathrm{V}$ \\
\hline $\mathrm{O}-\mathrm{F}$ test (glucose) & Fermentation & Oxidation & Fermentation \\
\hline \multicolumn{4}{|l|}{ Assimilation of: } \\
\hline$N$-Acetyl-D-glucosamine & - & + & + \\
\hline L-Alanyl glycine & - & $\mathrm{W}$ & $+/ \mathrm{w}$ \\
\hline Glucose 6-phosphate & $\mathrm{W}$ & + & - \\
\hline Glucose1-phosphate & + & + & - \\
\hline D-Melibiose & - & + & + \\
\hline Monomethyl succinate & $\mathrm{W}$ & - & - \\
\hline L-Ornithine & - & $\mathrm{W}$ & $+/ \mathrm{w}$ \\
\hline L-Rhamnose & - & - & + \\
\hline L-Threonine & - & $\mathrm{W}$ & $+/ \mathrm{w}$ \\
\hline Urocanic acid & - & - & + \\
\hline \multicolumn{4}{|l|}{ Acid production from: } \\
\hline Arbutin & - & + & + \\
\hline Mannitol & - & $\mathrm{W}$ & - \\
\hline Melezitose & - & $\mathrm{W}$ & - \\
\hline Melibiose & - & + & + \\
\hline Methyl $\alpha$-D-glucoside & - & $\mathrm{W}$ & $\mathrm{W}$ \\
\hline Raffinose & - & $\mathrm{W}$ & $+/ \mathrm{w}$ \\
\hline Rhamnose & - & - & + \\
\hline Ribose & $\mathrm{W}$ & $\mathrm{W}$ & - \\
\hline Sorbitol & - & $\mathrm{W}$ & - \\
\hline Xylitol & - & $\mathrm{W}$ & $+/ \mathrm{w}$ \\
\hline D-Xylose & + & - & + \\
\hline DNA $G+C$ content $(\mathrm{mol} \%)$ & $34 \cdot 2$ & $31 \cdot 8$ & $33 \cdot 4-35 \cdot 7$ \\
\hline
\end{tabular}




\section{Description of Flammeovirga arenaria nom. rev., comb. nov.}

Synonym: 'Microscilla arenaria' Lewin 1969

Flammeovirga arenaria (a.re.na'ria. L. fem. adj. arenarius pertaining to sand, referring to the source of the organism).

Displays the following properties in addition to those given in the genus description. Cells are long rods, $0.5-0.9 \mu \mathrm{m}$ wide and $2 \cdot 0-40 \mu \mathrm{m}$ long or longer. Cell mass is orange. Colonies spread and produce large gelase fields and deep craters in agar plates. Growth is detected at $10-30{ }^{\circ} \mathrm{C}$ with the optimum growth yield at $25^{\circ} \mathrm{C}$. The $\mathrm{pH}$ range for growth is 6-8 with the optimum growth yield at $\mathrm{pH} 7$. Growth occurs at $1-5 \% \mathrm{NaCl}$ with the optimum growth yield at $3 \%$. Oxidase, catalase and urease activities are negative. Agar, alginic acid, aesculin and starch are degraded, but carboxymethylcellulose, cellulose, chitin, DNA, inulin, gelatin, Tween 80 and tyrosine are not degraded. Casein is weakly degraded. $\mathrm{H}_{2} \mathrm{~S}$ is produced, but indole is not. O-F test of glucose is oxidative. Utilization (Biolog GN2 microplate data) is observed for D-melibiose, $\alpha$-cyclodextrin, dextrin, L-fucose, glycogen, D-galactose, gentiobiose, $\alpha$ D-glucose, $N$-acetyl-D-glucosamine, $\alpha$-D-lactose, lactulose, maltose, L-glutamic acid, glycyl L-aspartic acid, glucose 1phosphate, cellobiose, D-mannose, glycyl L-glutamic acid and glucose 6-phosphate. Weakly positive for utilization of alaninamide, L-ornithine, DL-lactic acid, L-alanine, L-alanyl glycine, L-aspartic acid and L-threonine, but negative for urocanic acid, L-rhamnose and monomethyl succinate. Acid production (API $50 \mathrm{CH}$ data) is positive for galactose, glucose, mannose, $\mathrm{N}$-acetylglucosamine, amygdalin, arbutin, aesculin, cellobiose, maltose, lactose, melibiose, trehalose, starch, glycogen, gentiobiose and L-fucose and weakly positive for ribose, fructose, mannitol, sorbitol, methyl $\alpha$-Dmannoside, methyl $\alpha$-D-glucoside, salicin, sucrose, melezitose, raffinose, xylitol and 5-ketogluconate. Acid is not produced from D-xylose or rhamnose. The major cellular fatty acids are iso-C15:0, C14:0, C16:0 3-OH, $\mathrm{C} 20: 4 \omega 6,9,12,15 c, \mathrm{C} 16: 1 \omega 5 c$ and iso-C15:0 3-OH. The DNA $\mathrm{G}+\mathrm{C}$ content of the type strain is $31 \cdot 8 \mathrm{~mol} \%$.

The type strain is NBRC $15982^{\mathrm{T}}\left(=\mathrm{CIP} 109101^{\mathrm{T}}\right)$.

\section{Description of Flammeovirga yaeyamensis sp. nov.}

Flammeovirga yaeyamensis (ya.e.ya.men'sis. N.L. fem. adj. yaeyamensis referring to the Yaeyama Islands, from where the organisms were isolated).

Displays the following properties in addition to those given in the genus description. Cells are long rods, $0 \cdot 4-0.9 \mu \mathrm{m}$ wide and 1.7-90 $\mu \mathrm{m}$ long or longer. Cell mass is orange. Colonies spread and produce large gelase fields and deep craters in agar plates. Growth is detected at $15-35^{\circ} \mathrm{C}$ with the optimum growth yield at $30^{\circ} \mathrm{C}$. The $\mathrm{pH}$ range for growth is $6-10$ with the optimum growth yield at $\mathrm{pH} 7$. Growth occurs at $1-5 \% \mathrm{NaCl}$ with the optimum growth yield at $3 \%$. Oxidase activity is positive. Catalase activity is variable. Urease activity is negative. Agar, alginic acid, carboxymethylcellulose, DNA, aesculin, inulin, gelatin, starch and Tween 80 are degraded, but casein, cellulose, chitin and tyrosine are not degraded. $\mathrm{H}_{2} \mathrm{~S}$ is produced, but indole is not. $\mathrm{O}-\mathrm{F}$ test of glucose is fermentative. Utilization (Biolog GN2 microplate data) is observed for D-melibiose, urocanic acid, D-galactose, gentiobiose, L-rhamnose, $\mathrm{N}$ acetyl-D-glucosamine, cellobiose and glycyl L-glutamic acid. Positive or weakly positive for L-ornithine, $\alpha$-D-glucose, L-alanyl glycine, maltose and L-threonine, but negative for glucose 1-phosphate, monomethyl succinate and glucose 6-phosphate. Acid production (API 50CH data) is positive for D-xylose, galactose, glucose, mannose, rhamnose, $\mathrm{N}$ acetylglucosamine, amygdalin, arbutin, aesculin, salicin, cellobiose, maltose, lactose, melibiose, starch, glycogen and gentiobiose. Positive or weakly positive for methyl $\alpha$-D-glucoside, raffinose, xylitol and L-fucose. Acid is not produced from ribose, mannitol, sorbitol or melezitose. The

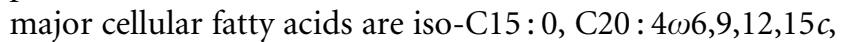
$\mathrm{C} 16: 0$ 3-OH, iso-C15:0 3-OH, C16:0 and $\mathrm{C} 14: 0$. The $\mathrm{G}+\mathrm{C}$ content of DNA is $33 \cdot 4-35 \cdot 7 \mathrm{~mol} \%$.

The type strain is $\operatorname{IR} 25-3^{\mathrm{T}} \quad\left(=\mathrm{NBRC} 100898^{\mathrm{T}}=\mathrm{CIP}\right.$ $\left.109099^{\mathrm{T}}\right)$. Four other strains, IR27-3 (=NBRC 100899), IR28-1 (=NBRC 100900), IS22-1 (=NBRC 100901) and IS26-1 ( = NBRC 100902), are available as reference strains.

\section{Acknowledgements}

We thank Dr K. Isono (NBRC) for valuable suggestions on the manuscript, Dr K. Hamana (Gunma University) for polyamine analysis and Dr J.P. Euzéby (École Nationale Vétérinaire) for advising on the etymology of the taxa.

\section{References}

Barrow, G. I. \& Feltham, R. K. A. (1993). Cowan and Steel's Manual for the Identification of Medical Bacteria. Cambridge: Cambridge University Press.

Brosius, J., Palmer, M. L., Kennedy, P. J. \& Noller, H. F. (1978). Complete nucleotide sequence of a $16 \mathrm{~S}$ ribosomal RNA gene from Escherichia coli. Proc Natl Acad Sci U S A 75, 4801-4805.

Ezaki, T., Hashimoto, Y. \& Yabuuchi, E. (1989). Fluorometric deoxyribonucleic acid- deoxyribonucleic acid hybridization in microdilution wells as an alternative to membrane filter hybridization in which radioisotopes are used to determine genetic relatedness among bacterial strains. Int J Syst Bacteriol 39, 224-229.

Fautz, E. \& Reichenbach, H. (1980). A simple test for flexirubin-type pigments. FEMS Microbiol Lett 8, 87-91.

Felsenstein, J. (1985). Confidence limits on phylogenies: an approach using the bootstrap. Evolution 39, 783-791.

Gutell, R. R., Larsen, N. \& Woese, C. R. (1994). Lessons from an evolving rRNA: $16 \mathrm{~S}$ and $23 \mathrm{~S}$ rRNA structures from a comparative perspective. Microbiol Rev 58, 10-26.

Hamana, K., Nakagawa, Y. \& Yamasato, K. (1995). Chemotaxonomic significance of polyamine distribution patterns in the FlavobacteriumCytophaga complex and related genera. Microbios 81, 135-145. 
Hosoya, R. \& Hamana, K. (2003). Absence of cellular triamines in four novel flavobacteria located in Flavobacterium-FlexibacterCytophaga complex. Ann Gunma Health Sci 24, 13-16.

Hugh, R. \& Leifson, E. (1953). The taxonomic significance of fermentative versus oxidative metabolism of carbohydrates by various Gram negative bacteria. J Bacteriol 66, 24-26.

Kimura, M. (1980). A simple method for estimating evolutionary rates of base substitutions through comparative studies of nucleotide sequences. J Mol Evol 16, 111-120.

Lau, K. W. K., Ng, C. Y. M., Ren, J., Lau, S. C. L., Qian, P.-Y., Wong, P.-K., Lau, T. C. \& Wu, M. (2005). Owenweeksia hongkongensis gen. nov., sp. nov., a novel marine bacterium of the phylum 'Bacteroidetes'. Int J Syst Evol Microbiol 55, 1051-1057.

Lewin, R. A. (1969). A classification of flexibacteria. J Gen Microbiol 58, 189-206.

Lewin, R. A. \& Lounsbery, D. M. (1969). Isolation, cultivation and characterization of flexibacteria. J Gen Microbiol 58, 145-170.

Mesbah, M., Premachandran, U. \& Whitman, W. B. (1989). Precise measurement of the $\mathrm{G}+\mathrm{C}$ content of deoxyribonucleic acid by highperformance liquid chromatography. Int J Syst Bacteriol 39, 159-167.

Nakagawa, Y. (2004). Taxonomic studies of Cytophaga-like bacteria. Microbiol Cult Coll 20, 41-51.

Nakagawa, Y. \& Yamasato, K. (1993). Phylogenetic diversity of the genus Cytophaga revealed by $16 \mathrm{~S}$ rRNA sequencing and menaquinone analysis. J Gen Microbiol 139, 1155-1161.

Nakagawa, Y., Hamana, K., Sakane, T. \& Yamasato, K. (1997). Reclassification of Cytophaga aprica (Lewin 1969) Reichenbach 1989 in Flammeovirga gen. nov. as Flammeovirga aprica comb. nov. and of Cytophaga diffluens (ex Stanier 1940; emend. Lewin 1969) Reichenbach 1989 in Persicobacter gen. nov. as Persicobacter diffluens comb. nov. Int J Syst Bacteriol 47, 220-223.

Nakagawa, Y., Sakane, T., Suzuki, M. \& Hatano, K. (2002). Phylogenetic structure of the genera Flexibacter, Flexithrix, and Microscilla deduced from $16 \mathrm{~S}$ rRNA sequence analysis. J Gen Appl Microbiol 48, 155-165.
Perry, L. B. (1973). Gliding motility in some non-spreading flexibacteria. J Appl Microbiol 36, 227-232.

Reichenbach, H. (1989a). Genus I Cytophaga Winogradsky 1929, $577^{\mathrm{AL}}$, emend. In Bergey's Manual of Systematic Bacteriology, vol. 3, pp. 2015-2050. Edited by J. T. Staley, M. P. Bryant, N. Pfennig \& J. G. Holt. Baltimore: Williams \& Wilkins.

Reichenbach, H. (1989b). Genus Microscilla Pringsheim 1951, 140, emend. Lewin 1969, 194 ${ }^{\mathrm{AL}}$. In Bergey's Manual of Systematic Bacteriology, vol. 3, pp. 2071-2073. Edited by J. T. Staley, M. P. Bryant, N. Pfennig \& J. G. Holt. Baltimore: Williams \& Wilkins.

Rüger, H.-J. \& Krambeck, H.-J. (1994). Evaluation of the BIOLOG substrate metabolism system for classification of marine bacteria. Syst Appl Microbiol 17, 281-288.

Saitou, N. \& Nei, M. (1987). The neighbor-joining method: a new method for reconstructing phylogenetic trees. Mol Biol Evol 4, 406-425.

Schmidt, K., Connor, A. \& Britton, G. (1994). Analysis of pigments: carotenoids and related polyenes. In Chemical Methods in Prokaryotic Systematics, pp. 403-461. Edited by M. Goodfellow \& A. G. O’Donnell. West Sussex: Wiley.

Smibert, R. M. \& Krieg, N. R. (1981). General characterization. In Manual of Methods for General Bacteriology, pp. 409-443. Edited by P. Gerhardt, R. G. E. Murray, R. N. Costilow, E. W. Nester, W. A. Wood, N. R. Krieg \& G. B. Phillips. Washington, DC: American Society for Microbiology.

Suzuki, M., Nakagawa, Y., Harayama, S. \& Yamamoto, S. (2001). Phylogenetic analysis and taxonomic study of marine Cytophaga-like bacteria: proposal for Tenacibaculum gen. nov. with Tenacibaculum maritimum comb. nov. and Tenacibaculum ovolyticum comb. nov., and description of Tenacibaculum mesophilum sp. nov. and Tenacibaculum amylolyticum sp. nov. Int J Syst Evol Microbiol 51, 1639-1652.

Thompson, J. D., Gibson, T. J., Plewniak, F., Jeanmougin, F. \& Higgins, D. G. (1997). The CLUSTAL_X windows interface: flexible strategies for multiple sequence alignment aided by quality analysis tools. Nucleic Acids Res 25, 4876-4882. 